\title{
AN EVALUATION OF MOTIVATIONS AND PERCEIVED IMPACTS OF OPEN GOVERNMENT DATA
}

\author{
Pin-Yu Chu ${ }^{1}$ and Feng-Wu Lee ${ }^{2}$ \\ ${ }^{I}$ Professor, Department of Public Administration, National Chengchi University, Taipei, Taiwan. \\ ${ }^{2}$ Post Doctor Researcher, Institutional Research Center, Soochow University, Taipei, Taiwan
}

\begin{abstract}
Open government data (OGD), as an enabler of transparent, accountable, and effective public administration institutions, becomes more and more important nowadays, so does the need for effective ways to understand the needs of its users. In research, we identify important motivations, and expectation of various OGD users, including people from academia, non-profit organization, private sector, and government. We conduct a large-scale online survey of users of OGD in Taiwan. Our analyses are based information from 3,179 valid respondents. Our results indicate that these four types of OGD users share similar motivations, indicating that they care about social issues and public values such as transparency, citizen and customer needs, etc. The impacts of OGD has not significantly recognized by many OGD users yet. Thus, government should further explore user needs in order to encourage the use and development of OGD.
\end{abstract}

\section{KEYWORDS}

Open Data, Impact Assessment, E-Government, E-Participation

\section{WORLD TRENDS OF OPEN GOVERNMENT DATA}

Open Government Data (OGD), one of the most important development of e-governance, allow various users with the opportunity to access government data, conduct value-added applications, and provide creative services to improve the well-being of society. Nowadays, OGD has become an enabler of transparent, accountable, and effective public administration institutions (Chu \& Tseng 2016). Significant resources go into OGD policy development and initiatives and governments worldwide are increasingly releasing non-personal data, and data that can be used freely, re-used, distributed by anyone, and machine-readable to public users (Martin, Rosario \& Perez 2016). For example, until 7th February 2019, the US OGD platform has more than 304,031 datasets (https://www.data.gov); the UK OGD platform has more than 47,230 datasets (https://data.gov.uk); and the Japanese OGD platform has more than 22,685 datasets (http://www.data.go.jp), etc. Since 2010, the United Nations (UN) has been conducting research on OGD, continue to emphasize its importance for citizen engagement, and even implement projects to utilize government open data in the context of the 2030 Agenda for Sustainable Development (https://publicadministration.un.org/en/ogd).

OGD becomes more and more important nowadays, so does the need for effective ways to evaluate its quality, benefits, and even impacts. The expected benefits of OGD are widely advocated but still not being realized, and a better understanding of the phenomenon is required for the growing field to progress. Through a structured review of open data within the e-government and public administration field, Kvamsdal (2017) found that OGD research overwhelmingly focus on the supply-side, and lack the basic understandings of the demand-side, i.e., OGD users including academic researchers, non-government organization, private companies, tech entrepreneurs, data scientists, and developers of all stripes. Moreover, international organizations, such as the Open Data Barometer, Open Data Index, Open Data Census, European PSI Scoreboard, and Open Data Compass, all adopt various methods to evaluate the quality of OGD and its portals. However, most OGD evaluation indicators emphasize on the importance of economic and political aspects of OGD (Viscusi, Castelli \& Batini 2014; UN 2016). There is still a lack of attention on dimensions of society and sustainability (Lee \& Chu 2018).

What are the motivations of various OGD users? Will their profession or career cause any difference? Whether currently available OGD really contribute many anticipated political, social, and economic benefits? 
From the users' point of view, we discuss whether OGD really have significant impacts as many government officials and academic researchers expect. The outline of the paper is as follows. The next section of this paper introduces literature of OGD, focusing on the OGD users' motivations and their expectation of OGD benefits and estimation of OGD impacts. Afterwards, we introduce the status of OGD in Taiwan. We develop a motivation and impact framework, and the framework is examined using data from a large-scale survey of OGD users who reported their motivations, expectations, usage patterns, and perceptions of impacts of OGD. We analyze the survey data, and from the results we derive implications for public policy.

\section{MOTIVATIONS, EXPECTED BENEFITS, AND IMPACTS OF OGD}

Friedland and Gross (2010), from the perspective of good governance, emphasize that the development and application of OGD should not deviate from its fundamental goal of responding to public values such as participation, transparency, accountability, sustainability, equity, citizen engagement, etc. Weerakkody et al. (2017) showed that public norms such as efficiency, transparency, and accountability have motivated governments to open data and promote its use. Kostovski et al. (2012) mentioned that governments worldwide all encourage the public to use government open data to develop value-added applications, start innovative business, and provide creative public services. Chan (2013) identified two key motivations for using OGD, i.e., democratic and economic purposes. Safarov et al. (2017) reviewed 70 papers that discussed motivations of OGD utilization. The most important OGD motivation is to bring various innovation, such as motivations to create economic values from business-driven innovation or to develop co-produce public services. Other important motivations include improving government transparency, efficiency, and decision-making, anti-corruption, purposes for academic research, and hackathon competitions. In particular, Jetzek et al. (2014) categorized motivations of private sector to use OGD into two-fold: (1) participation - to generate social value; and (2) innovation - to generate firsthand value of new ideas, processes, service, and product to exchange on markets. Based on the literature review, the motivations of OGD may range from personal benefits, co-operation with government, job needed, business profit and the social welfare. In practice, we need to understand the diversity in user needs (Kvamsdal, 2017).

OGD is important because the more accessible, discoverable, and usable data is, the more impact it can have. These impacts include, but are not limited, cost savings, efficiency for business, improved civic services, informed policy, performance planning, research and scientific discoveries, transparency and accountability, and increased public participation in the democratic dialogue (https://www.data.gov/impact). Benefits of open data may range from the political and democratic benefits to economic growth and stimulation of competitiveness and innovation (Davies \& Perini, 2016). For example, Safarov et al. (2017) reviewed 83 articles and identified six prominent effects of OGD, the most frequently mentioned is transparency and accountability, next is economic development, citizen participation, public service development, social value, and the last one is trust of citizens. UN (2018) advocated that OGD contributes to participation and collaboration among public, private and civil society sectors. Moreover, UN (2016) reported that OGD allows people to develop new commercial services (e.g., new apps for education), generate new employment opportunities, and facilitate the creation of start-ups. World Bank (2014) also showed that startups and small and medium enterprises can benefit from the re-use of government data. Besides the political, democratic and economic impacts, open data also enable social monitoring (Worthy 2015). For example, in the field of environment protection, open data can elevate environmental awareness of citizens and can be utilized by green groups as a tool to supervise government and corporations.

\section{OGD IN TAIWAN}

The National Development Council (NDC), Taiwan, launched the Government Open Data Platform (data.gov.tw) to provide a one-stop contact for OGD inquiry services in 2012. Three OGD principles that Taiwan government follows are: (1) open data for public and enterprise use; (2) free in principle, charging as the exception, and (3) automatic and systematic release and exchange of large volume of data (NDC 2015). Since 2014, civil groups such as g0v, Taipei Computer Association, the Open Data Alliance, etc., have worked with the central government and local governments in a spirit of interactive participation and cooperation to 
promote open data. Until 7th February 2019, the OGD platform has more than 39,386 datasets and 342 Application Public Interfaces (APIs). Most datasets on the OGD platform are 3-star, which means datasets are available as machine-readable structured data plus non-proprietary format. Open Knowledge International has published global open data index 2016, showing that Taiwan topped the index for two consecutive years (NDC 2017). Of the 15 key categories used to gauge the state of OGD, Taiwan topped 12 with 100 percent openness, such as land ownership, location and weather forecast, administrative boundaries, air quality, company register, draft legislation, election results, government budget, national maps, national statistics and procurement. Taiwan government will continue promoting OGD and releasing accurate and easy-to-use public data in a timely manner.

\section{METHODS AND PROCEDURES}

Our research team examine motivations, usage patterns, expectations and perceptions of the current and future impacts of OGD in the context of a user-centric approach. We incorporate a wide variety of important factors from previous research into a framework. In 2017, with the assistance of the NDC and Industrial Development Bureau (IDB) of Ministry of Economics, we conduct an online survey and made detailed assessments of the OGD users in Taiwan. This section details the subsequent constructs and questionnaire items and the survey settings to collect the empirical data from OGD users. The questionnaire was reviewed by a committee (a team of government officials and experts from various domains like public administration, public management, and information management) and was pretested on several people to verify the clarity of the questions and to ensure its content validity. We post the questionnaire information and URL on the Government Open Data Platform (data.gov.tw), social networks, and Facebook fan pages related to OGD. In addition, we sent survey invitation email to people who participated in various OGD contests host by IDB.

We identify nine major motivations of OGD usage, such as "meet personal curiosity", "learn new technique", "realize the operation of the government", "supervise the government", "help government become more efficiency", "respond requests from organizations or superiors", "meet citizen's needs of public service", "make business profits" and "discover potential social issues" (see table 2). We also identify the expected benefits and long term impact assessment of OGD. These items include not only the aspects of "transparency", "accountability", "participation and collaboration" but also the aspects of "political impacts", "social impacts" and "economic impacts" (see table 3).

Overall, 4,095 OGD users finished the questionnaire. We focus on the different types of OGD users, such as "private sector", "government", "academia" and "NPO" and the rest are housekeepers, students, people currently unemployed, etc. Lee and Chu (2018) first compared different motivations and impact assessment between the heavy and the light OGD users. Their results indicated that the heavy users have more internal/external driving forces than the light users. The top three motivating factors are to meet citizen's needs of public service, to realize the operation of the government, and to discover potential social issues. Moreover, the heavy users have higher awareness of both the mid-term and the long-term impacts than the light users do, indicating that heavy users are more likely to believe that OGD can bring the influence of transparency, participation, and accountability, and create political, social, and economical benefits.

\section{RESULTS}

What are the motivations of various OGD users? Will their profession or career cause any difference? Different from Lee and Chu (2018), we focus on the difference among various types of the OGD users. Among all respondents, 1,843 (58\%) are employees of private companies, $969(30.5 \%)$ are government employees, 225 $(7.1 \%)$ works in academia, $142(4.5 \%)$ works for NPOs. In these four types of OGD users, there are more women $(53 \%)$ who responded, indicating that female are slightly more interested in using OGD. The education level of these respondents are high, about $89.4 \%$ of the respondents having completed college or higher degrees. Many of the respondents are in the age group of 31-49, indicating that these OGD users are highly educated and mature (see Table 1). Table 1 also shows that among all the OGD data, "health and welfare $(12.4 \%)$ ", "environment and weather (12.1\%) and "law and administration (12.1\%)" are the top three data that these OGD users are most interested in. Although half of these OGD users work for private companies, the 
"commercial and economics" data only ranks the fifth. In addition, most respondents reveal that they frequently use OGD to run statistical analysis $(21.4 \%)$, to conduct academic research $(12.3 \%)$, and to develop online service $(12.1 \%)$.

Table 2 demonstrates the comparison of motivations among the four types of OGD users. The top three motivating factors for OGD users who are corporate employees are "meet citizen's or customers' needs of public service", "realize the operation of the government" and "discover potential social issues". The top three motivating factors for OGD users who are government employees are "meet citizen's or customers' needs of public service", "realize the operation of the government" and "help government become more efficiency". The top three motivating factors for OGD users from academia are "meet citizen's or customers' needs of public service", "realize the operation of the government" and "discover potential social issues". The top three motivating factors for OGD users from NPOs are "to meet citizen's or customers' needs of public service", "realize the operation of the government" and "discover potential social issues".

Our results show that these four types of OGD users share similar motivations, indicating that they really care about social issues and public values such as transparency, citizen/customer needs, etc. Surprisingly, even for OGD users from private sector, the motivation "make business profits" is the least important one.

Table 1. Demographics of the OGD users

\begin{tabular}{|c|c|c|c|c|c|c|c|c|c|}
\hline \multicolumn{2}{|c|}{ Gender } & \multicolumn{3}{|c|}{ Age } & & \multicolumn{4}{|c|}{ Education } \\
\hline $\begin{array}{l}\text { Male } \\
1,493 \\
(47 \%) \\
\end{array}$ & $\begin{array}{c}\text { Female } \\
1,686 \\
(53 \%) \\
\end{array}$ & $\begin{array}{c}\leq 30 \\
473 \\
(14.9 \%) \\
\end{array}$ & $\begin{array}{c}31-39 \\
1,126 \\
(35.4 \%) \\
\end{array}$ & $\begin{array}{c}40-49 \\
1,106 \\
(34.8 \%) \\
\end{array}$ & $\begin{array}{c}50+ \\
474 \\
(14.9 \%) \\
\end{array}$ & $\begin{array}{c}\text { High School } \\
336 \\
(10.6 \%) \\
\end{array}$ & $\begin{array}{c}\text { College } \\
523 \\
(16.5 \%) \\
\end{array}$ & $\begin{array}{c}\text { University } \\
1535 \\
(48.3 \%) \\
\end{array}$ & $\begin{array}{c}\text { Master } \\
785 \\
(24.7 \%) \\
\end{array}$ \\
\hline \multicolumn{10}{|c|}{ Top 3 Purposes of using OGD } \\
\hline \multicolumn{3}{|c|}{$\begin{array}{c}\text { To run statistical analysis } \\
1,100(21.4 \%)\end{array}$} & \multicolumn{4}{|c|}{$\begin{array}{l}\text { To conduct academic research } \\
\qquad 636(12.3 \%)\end{array}$} & \multicolumn{3}{|c|}{$\begin{array}{l}\text { To develop online service } \\
623(12.1 \%)\end{array}$} \\
\hline \multicolumn{2}{|c|}{ Health and welfare } & \multicolumn{2}{|c|}{$\begin{array}{l}\text { Environment and } \\
\text { weather }\end{array}$} & \multicolumn{2}{|c|}{$\begin{array}{l}\text { Law and } \\
\text { Administration }\end{array}$} & \multirow{2}{*}{\multicolumn{2}{|c|}{$\begin{array}{l}\text { Workforce and } \\
\text { employment }\end{array}$}} & \multicolumn{2}{|c|}{$\begin{array}{l}\text { Commercial and } \\
\text { economics }\end{array}$} \\
\hline \multicolumn{2}{|c|}{$972(12.4 \%)$} & \multicolumn{2}{|c|}{$948(12.1 \%)$} & \multicolumn{2}{|c|}{$798(12.1 \%)$} & & & \multicolumn{2}{|c|}{$735(9.4 \%)$} \\
\hline
\end{tabular}

Table 2. Comparison of motivations among the four types of OGD users

\begin{tabular}{lccccc}
\hline Motivations of OGD users & Private & $\begin{array}{c}\text { Government } \\
\text { Mean }(\text { SD })\end{array}$ & Academia & NPO & $\begin{array}{c}\text { ANOVA } \\
\text { Significance }\end{array}$ \\
\hline $\begin{array}{l}\text { To meet personal curiosity } \\
\text { To learn new technique }\end{array}$ & $3.47(0.845)$ & $3.42(0.846)$ & $3.53(0.850)$ & $3.49(0.840)$ & .261 \\
$\begin{array}{l}\text { To realize the operation of the } \\
\text { government }\end{array}$ & $3.81(0.771)$ & $3.75(0.778)$ & $3.88(0.832)$ & $3.92(0.744)$ & $.019^{*}$ \\
$\begin{array}{l}\text { To supervise the government } \\
\text { To help government become } \\
\text { more efficiency }\end{array}$ & $3.88(0.747)$ & $3.89(0.773)$ & $3.94(0.797)$ & $3.91(0.780)$ & .652 \\
$\begin{array}{l}\text { To respond requests from } \\
\text { organizations or superiors }\end{array}$ & $3.87(0.834)$ & $3.49(0.859)$ & $3.52(0.856)$ & $3.54(0.856)$ & .664 \\
$\begin{array}{l}\text { To meet citizen's or customers } \\
\text { needs of public service }\end{array}$ & $3.61(0.846)$ & $3.72(0.792)$ & $3.55(0.886)$ & $3.77(0.829)$ & $.001^{* * *}$ \\
$\begin{array}{l}\text { To make business profits } \\
\text { To discover potential social issues }\end{array}$ & $3.84(0.78)$ & $3.90(0.789)$ & $4.02(0.767)$ & $4.04(0.794)$ & .069 \\
\hline
\end{tabular}

Grey are the top 3 motivation and light grey is the last one.

We further use ANOVA to compare the mean value of each motivation for these four groups of OGD users. Table 2 shows that these four groups of OGD users assess four motivations significantly different, i.e., "learn new technique", "respond requests from organizations or superiors", "make business profits" and "discover potential social issues". The motivation to discover potential social issues is significantly higher for researchers in academia. Although the motivation to make business profits for users from private sector is relatively low but still significantly higher than the other three groups of OGD users. 
Table 3. Comparison of impacts among the four types of OGD users

\begin{tabular}{|c|c|c|c|c|c|}
\hline \multirow{2}{*}{$\begin{array}{l}\text { Construct } \\
\text { Midterm Impact }\end{array}$} & \multicolumn{2}{|c|}{ Questions } & \multirow{2}{*}{$\begin{array}{l}\text { Mean }(S D) \\
\text { Academia }\end{array}$} & \multirow{2}{*}{$\begin{array}{l}N=\text { sample size } \\
\text { NPO }\end{array}$} & \multirow{2}{*}{$\begin{array}{l}\text { Significance } \\
\text { ANOVA }\end{array}$} \\
\hline & Private & Government & & & \\
\hline \multirow{4}{*}{$\begin{array}{l}\text { Transparency } \\
(\mathrm{Q} 1, \mathrm{Q} 2)\end{array}$} & \multicolumn{5}{|c|}{ OGD brings greater understanding of internal information for citizens } \\
\hline & $3.81(0.696)$ & $3.72(0.692)$ & $3.84(0.745)$ & $3.75(0.774)$ & $0.005 * *$ \\
\hline & \multicolumn{4}{|c|}{ OGD leads to more transparency for government. } & \multirow[b]{2}{*}{$0.000 * * *$} \\
\hline & $3.92(0.721)$ & $3.82(0.738)$ & $4.01(0.716)$ & $3.99(0.794)$ & \\
\hline \multirow{4}{*}{$\begin{array}{l}\text { Accountability } \\
\text { (Q3, Q4) }\end{array}$} & OGD brings & atability of gov & ent effectively. & & \multirow[b]{2}{*}{$0.000 * * *$} \\
\hline & $3.86(0.757)$ & $3.72(0.793)$ & $3.93(0.735)$ & $3.87(0.832)$ & \\
\hline & \multicolumn{4}{|c|}{ OGD helps to fight against government corruption } & \multirow[b]{2}{*}{$0.010 * *$} \\
\hline & $3.69(0.919)$ & $3.57(0.877)$ & $3.69(0.897)$ & 3.64(1.020) & \\
\hline \multirow{4}{*}{$\begin{array}{l}\text { Participation/ } \\
\text { Collaboration } \\
(\mathrm{Q} 5, \mathrm{Q} 6)\end{array}$} & OGD promo & lic engagemen & arginalized gr & oups. & \multirow[b]{2}{*}{$0.000 * * *$} \\
\hline & $3.76(0.820)$ & $3.64(0.820)$ & $3.77(0.833)$ & $3.87(0.841)$ & \\
\hline & \multicolumn{4}{|c|}{ Citizens and government can collaborate in solving social problems. } & \multirow[b]{2}{*}{$0.000 * * *$} \\
\hline & $3.79(0.792)$ & $3.68(0.774)$ & $3.84(0.799)$ & $3.97(0.790)$ & \\
\hline \multirow{4}{*}{$\begin{array}{l}\text { Political } \\
\text { Impacts } \\
\left(Q^{2}, Q 8\right)\end{array}$} & \multicolumn{4}{|c|}{ Presently, I think OGD can enhance citizens' trust in government. } & \multirow[b]{2}{*}{$0.001 * *$} \\
\hline & $3.78(0.814)$ & $3.66(0.789)$ & $3.79(0.843)$ & $3.86(0.839)$ & \\
\hline & \multicolumn{5}{|c|}{ In the next five years, I expect OGD will enhance citizens' trust in government. $(N=154)$} \\
\hline & $2.57(0.956)$ & $2.31(0.895)$ & $2.41(0.795)$ & $2.17(1.169)$ & 0.365 \\
\hline \multirow{2}{*}{ Social impacts } & \multicolumn{5}{|c|}{$\begin{array}{l}\text { Presently, I think that with OGD, the public services have helped to solve the } \\
\text { environmental problems }\end{array}$} \\
\hline & $3.57(0.780)$ & $3.52(0.761)$ & $3.60(0.824)$ & $3.56(0.871)$ & 0.325 \\
\hline \multirow{4}{*}{$(\mathrm{Q} 9, \mathrm{Q} 10)$} & \multicolumn{5}{|c|}{ In the next decade, I expect that OGD will help to solve the environmental problems $(N=210)$} \\
\hline & $2.32(0.845)$ & $2.20(0.964)$ & $2.79(0.976)$ & 2.82(1.168) & $0.028 *$ \\
\hline & \multicolumn{5}{|c|}{$\begin{array}{l}\text { Presently, I think that with OGD, the public services have contributed to greater inclusion } \\
\text { for marginalized groups in our society. }\end{array}$} \\
\hline & $3.31(0.807)$ & $3.28(0.763)$ & $3.19(0.866)$ & $3.27(0.866)$ & 0.204 \\
\hline \multirow[t]{3}{*}{ (Q11,Q12) } & \multicolumn{5}{|c|}{$\begin{array}{l}\text { In the next decade, I expect that OGD will help contribute to greater inclusion for } \\
\text { marginalized groups in our society. }(N=386)\end{array}$} \\
\hline & $2.88(1.043)$ & $2.68(0.999)$ & $2.89(0.971)$ & $2.67(1.138)$ & 0.343 \\
\hline & $\begin{array}{l}\text { Presently, I t } \\
\text { basic service }\end{array}$ & $\begin{array}{l}\text { at with OGD } 1 \\
\text { eople living in }\end{array}$ & $\begin{array}{l}\text { elped governn } \\
\text { ty, gender ine }\end{array}$ & $\begin{array}{l}\text { ents to facilitate acc } \\
\text { quality and unemplo }\end{array}$ & \\
\hline \multirow[t]{3}{*}{ (Q13,Q14) } & $3.30(0.856)$ & $3.25(0.823)$ & $3.25(0.873)$ & $3.31(0.924)$ & 0.389 \\
\hline & $\begin{array}{l}\text { In the next d } \\
\text { basic service }\end{array}$ & $\begin{array}{l}\text { I expect that } \mathrm{O} \\
\text { eople living in }\end{array}$ & $\begin{array}{l}\text { vill help gover } \\
\text { ty, gender ine }\end{array}$ & $\begin{array}{l}\text { ments to facilitate a } \\
\text { quality and unemplo }\end{array}$ & to $(N=460)$ \\
\hline & $2.32(0.895)$ & $2.24(0.909)$ & $2.44(0.908)$ & $2.38(0.805)$ & 0.585 \\
\hline & $\begin{array}{l}\text { The develop } \\
\text { now benefit }\end{array}$ & $\begin{array}{l}\text { f start-ups and } \\
\text { he use of OGD }\end{array}$ & and Medium & Enterprises (SMEs) & iwan \\
\hline Economic & $3.65(0.717)$ & $3.52(0.695)$ & $3.64(0.712)$ & $3.65(0.746)$ & $0.000 * * *$ \\
\hline $\begin{array}{l}\text { 1mpacts } \\
\text { (Q15,Q16) }\end{array}$ & $\begin{array}{l}\text { The use of } \mathrm{O} \\
\text { new employl }\end{array}$ & $\begin{array}{l}\text { lows people to } \\
\text { pportunities an }\end{array}$ & $\begin{array}{l}\text { op new comm } \\
\text { litating the cre }\end{array}$ & $\begin{array}{l}\text { rcial services, thus } \\
\text { ation of start-ups }\end{array}$ & ating \\
\hline & $3.71(0.716)$ & $3.56(0.715)$ & $3.72(0.735)$ & $3.76(0.762)$ & $0.000 * * *$ \\
\hline
\end{tabular}

Due to the early stage of policy adoption, we also identify the expected benefits and long term impact assessment of OGD. These items include the aspects of "political impacts", "social impacts" and "economic impacts". Among all respondents, the mean of "Presently, I think OGD can enhance citizens' trust in government (Q7)" is 3.74. The answer of Q7 is 1 and 2 (strongly disagree and disagree) will answer the question "In the next five years, I expect OGD will enhance citizens' trust in government (Q8)". The mean of Q8 is 2.45 , it changes from 1.74 (mean of Q7's answer is 1 and 2) to 2.45. It indicate that the "political impacts" will improve in the long term. ......It's same situation in "social impacts" (from Q9-Q14) etc.

Table 3 shows the mean and standard deviation of all impacts evaluated. The most valuable midterm impact perceived by OGD users are transparency. The top three perceived impacts for OGD users who are private sector employees are "transparency- leads to more transparency for government", "accountability- brings 
accountability of government effectively" and "transparency- brings greater understanding of internal information for citizens". The top three perceived impacts for OGD users who are government employees are "transparency- leads to more transparency for government", "accountability- brings accountability of government effectively" and "transparency- brings greater understanding of internal information for citizens". The top four perceived impacts for OGD users from academia are "transparency- leads to more transparency for government", "accountability- brings accountability of government effectively", "transparency-brings greater understanding of internal information for citizens" and "participation/collaboration- Citizens and government can collaborate in solving social problems". The top four perceived impacts for OGD users from NPOs are "transparency- leads to more transparency for government", "participation/collaboration- Citizens and government can collaborate in solving social problems", "participation/collaboration- OGD promotes public engagement of marginalized groups" and "accountability- brings accountability of government effectively." It shows that the OGD users from private sector and government share similar midterm impacts such as transparency and accountability. The OGD users from academia and NPOs share similar impacts such as transparency, accountability and participation/collaboration.

Our previous results show that these four types of OGD users share similar motivations, indicating that they really care about social issues and public values such as transparency, citizen/customer needs. Accordingly, our results in Table 3 indicate that in the perspective of these OGD users, OGD can also help government in achieving the mid-term public values such as transparency, accountability and participation/collaboration. Interestingly, although the economic motivation is not strong for these four types of OGD users, their assessment of economic impacts of OGD is high. Even surprisingly, the long term social impacts of OGD, such as environmental problems, poverty, gender inequality and unemployment, are not as promising.

We further use ANOVA to compare the mean value of each perceived impacts for these four groups of OGD users. Table 2 and Table 3 show that the motivations and impacts of these four groups of OGD users have some significant differences; Table 4 and Table 5 show the mean difference and the significance between 4 groups. Our results in the difference of OGD motivations: "To respond requests from organizations or superiors," government is higher than private and academic groups; "To make business profits," private group is higher than government and academic group; NPO is higher than government and academia; "To discover potential social issues," academia is higher than private group and government; NPO is higher than government and academia (see Table 4).

Table 4. The difference of motivation between 4 types OGD groups

\begin{tabular}{lllll}
\hline Motivations & Games-Howell & \multicolumn{2}{l}{ Means difference (SE) } & Significance \\
\hline To respond requests from & Government & Private & $0.106(0.32)$ & $.005^{* *}$ \\
\cline { 3 - 5 } organizations or superiors & & Academia & $0.169(0.64)$ & $.044^{*}$ \\
\hline To make business profits & Private & Government & $0.292(0.36)$ & $.000^{* * *}$ \\
\cline { 2 - 5 } & & Academia & $0.353(0.66)$ & $.000^{* * *}$ \\
\cline { 2 - 5 } & \multirow{2}{*}{ NPO } & Government & $0.207(0.073)$ & $.025^{*}$ \\
\cline { 2 - 4 } & & Academia & $0.268(0.092)$ & $.019^{*}$ \\
\hline To discover potential social issues & Academia & Private & $0.214(0.054)$ & $.001^{* *}$ \\
\cline { 2 - 5 } & & Government & $0.278(0.057)$ & $.000^{* * *}$ \\
\cline { 2 - 5 } & \multirow{2}{*}{ NPO } & Government & $0.186(0.069)$ & $.040^{*}$ \\
\cline { 2 - 4 } & & Academia & $0.250(0.072)$ & $.003^{* *}$ \\
\hline
\end{tabular}

We found the difference of impacts between 4 groups: "OGD brings greater understanding of internal information for citizens," private group has higher impacts than government; "OGD leads to more transparency for government," private and academic groups are higher than government; "OGD brings accountability of government effectively," private and academic groups are higher than government; "OGD helps to fight against government corruption," private group is higher than government; "OGD promotes public engagement of marginalized groups," private group and NPO are higher than government; "Citizens and government can collaborate in solving social problems," private group and NPO are higher than government; "Presently, I think OGD can enhance citizens' trust in government," private group has higher impacts than government; "The development of start-ups and SMEs in Taiwan now benefit from the use of OGD," private group has higher impacts than government; "The use of OGD allows people to develop new commercial services, thus generating new employment opportunities and facilitating the creation of start-ups," private, academic groups and NPO are higher than government (see Table 5). 
Table 5. The difference of perspectives impacts between 4 types of OGD groups

\begin{tabular}{|c|c|c|c|c|}
\hline \multirow{2}{*}{$\begin{array}{l}\text { Question } \\
\text { OGD brings greater understanding of } \\
\text { internal information for citizens }\end{array}$} & \multirow{2}{*}{$\begin{array}{l}\text { Group } \\
\text { Private }\end{array}$} & \multicolumn{2}{|c|}{ Means difference (SE) Scheffe } & \multirow{2}{*}{$\begin{array}{l}\text { Significance } \\
.010 *\end{array}$} \\
\hline & & Government & $0.094(0.28)$ & \\
\hline \multirow{2}{*}{$\begin{array}{l}\text { OGD leads to more transparency for } \\
\text { government }\end{array}$} & Private & Government & $0.098(0.029)$ & $0.009 * *$ \\
\hline & Academia & Government & $0.194(0.054)$ & $0.005 * *$ \\
\hline \multirow{2}{*}{$\begin{array}{l}\text { OGD brings accountability of government } \\
\text { effectively }\end{array}$} & Private & Government & $0.143(0.031)$ & $0.000 * * *$ \\
\hline & Academia & Government & $0.208(0.057)$ & $0.004 * *$ \\
\hline $\begin{array}{l}\text { OGD helps to fight against government } \\
\text { corruption }\end{array}$ & Private & Government & $0.120(0.036)$ & $0.011^{*}$ \\
\hline \multirow{2}{*}{$\begin{array}{l}\text { OGD promotes public engagement of } \\
\text { marginalized groups }\end{array}$} & Private & Government & $0.119(0.033)$ & $0.000 * * *$ \\
\hline & NPO & Government & $0.233(0.074)$ & $0.002 * *$ \\
\hline \multirow{2}{*}{$\begin{array}{l}\text { Citizens and government can collaborate in } \\
\text { solving social problems }\end{array}$} & Private & Government & $0.116(0.031)$ & $0.001 * *$ \\
\hline & NPO & Government & $0.294(0.071)$ & $0.000 * * *$ \\
\hline $\begin{array}{l}\text { Presently, I think OGD can enhance } \\
\text { citizens' trust in government }\end{array}$ & Private & Government & $0.117(0.032)$ & $0.004 * *$ \\
\hline $\begin{array}{l}\text { The development of start-ups and Small } \\
\text { and Medium Enterprises (SMEs) in Taiwan } \\
\text { now benefit from the use of OGD }\end{array}$ & Private & Government & $0.124(0.028)$ & $0.000 * * *$ \\
\hline \multirow{3}{*}{$\begin{array}{l}\text { The use of OGD allows people to develop } \\
\text { new commercial services, thus generating } \\
\text { new employment opportunities and } \\
\text { facilitating the creation of start-ups }\end{array}$} & Private & Government & $0.148(0.029)$ & $0.000 * * *$ \\
\hline & Academia & Government & $0.166(0.053)$ & $0.21 *$ \\
\hline & NPO & Government & $0.202(0.065)$ & $0.021 *$ \\
\hline
\end{tabular}

\section{CONCLUSION AND DISCUSSION}

We examine motivations, usage patterns, expectations and perceptions of the current and future impacts of OGD in the context of a user-centric approach. We incorporate with the assistance of the NDC and IDB in 2017, we conduct an online survey and collect 4,095 OGD users' questionnaire. Our previous results show that these four types of OGD users share similar motivations, indicating that they really care about social issues and public values such as transparency, citizen/customer needs. Surprisingly, even for OGD users from private sector, the motivation "make business profits" is the least important one. OGD can also help government in achieving the mid-term public values such as transparency, accountability and participation/collaboration. Interestingly, although the economic motivation is not strong for these four types of OGD users, their assessment of economic impacts of OGD is high. Even surprisingly, the long term social impacts of OGD, such as environmental problems, poverty, gender inequality and unemployment, are not as promising. Due to the early stage of policy adoption, the adoption of OGD policy might follow the Innovation Adoption Curve. Early stage users are innovators and opinions leaders. Among all 4 group of our survey, many of the respondents are highly educated and mature (24.7\% respondents are master or $\mathrm{PhD}$, only $10.7 \%$ respondents are high school). Might they care the policy issues more than their groups identity.

OGD is a tremendous resource. We all expect OGD to be of value, and where examples of how it has been used already exist. However, whether currently available OGD really contribute to good governance and have significant economic, political, and social impacts remains unclear. Many different groups of people and organizations who use and evaluate OGD differently, including government itself. In this paper, we develop a framework to evaluate the motivations of four different groups of OGD users, i.e., private sector, academia, public sector, and NGOs. We also assess the midterm impacts of OGD (i.e., transparency, accountability, and participation) and the long-term social, political, and economic impacts of OGD from the perspective of these four OGD users. Although Viscusi, Castelli and Batini (2014) argued that most of the open data sets based on a technology-driven perspective, rather than on a focus on the potential public or social value of the data to be published, our results show that the major four types of OGD users concern about social and welfare, environment and weather, and workforce employment. Thus, there is a disconnection between the supply side and the demand side of OGD. For this reason, government should further explore needs of various types of OGD users in order to provide useful open data. Moreover, our research findings lead us to believe that the 
impacts of OGD are not significantly recognized by these four types of OGD users. In particular, comparing to the political and economic impacts, user perspective of OGD's social impact is relatively low. More successful applications and development are still expected to achieve the long term impacts of OGD.

\section{ACKNOWLEDGEMENT}

This research is sponsored by the National Development Council (NDC) and the Ministry of Science and Technology in Taiwan. Members of this research team are research fellows of Taiwan e-Governance research center (TEG).

\section{REFERENCES}

Chan, C., 2013. From Open Data to Open Innovation Strategies: Creating E-Services Using Open Government Data. Proceedings of the Annual Hawaii International Conference on System Sciences, pp. 1890-1899. 10.1109/HICSS.2013.236.

Chu, P. Y., and Tseng, H. L., 2016. A Theoretical Framework for Evaluating Government Open Data Platform. Proceedings of the International Conference on Electronic Governance and Open Society: Challenges in Eurasia (EGOSE '16), St. Petersburg, Russia, pp. 135-142.

Davies, T. and Perini. F., 2016. Researching the emerging impacts of open data: revisiting the ODCC conceptual framework. The Journal of Community Informatics, Vol 12, No. 2, pp. 148-178.

Friedland, C. and Gross, T., 2010. Measuring the public value of e-government: Methodology of a south African case study. Proceedings of 2010 IST-Africa, Durban, Sourth Africa, pp. 19-21.

Jetzek, T. et al, 2014. Data-Driven Innovation through Open Government Data. Journal of Theoretical and Applied Electronic Commerce Research. Vol. 9, No. 2, pp. 100-120.

Kostovski, M. et al, 2012. Open Data Portal based on Semantic Web Technologies. In Proceeding of the 7th South East European Doctoral Student Conference. Thessaloniki, Greece. 10.13140/RG.2.2.23588.88969.

Kvamsdal, P., 2017. Open Government Data - A Literature Review and a Research Agenda. (Working paper: Dec 2017)

Retrieved Octomber 2, 2018 from https://www.researchgate.net/publication/326160800_Open_Government_Data__A_Literature_Review_and_a_Research_Agenda

Lee, L. W. and Chu, P.Y., 2018. A User Approach to Open Government Data Impact Assessment, Proceedings of the 18th European Conference on eGovernment, University of Santiago de Compostela, Oct 25-26.

Martin, A. S. et al, 2016. An International Analysis of the Quality of Open Government Data Portals. Social Science Computer Review, Vol. 34, No. 3, pp. 298-311.

National Development Council, 2015. An Outline of the Government Open Data Promotion Situation in Taiwan. Retrieved April 22, 2018, from http://www.ndc.gov.tw/en/News_Content.aspx?n=8C362E80B990A55C\&sms= 1DB6C6A8871CA043\&s=09819AC7E099BCD5

National Development Council, 2017. Global Open Data Index Taiwan topped for two consecutive years. Retrieved April 22, 2018, from http:// www.ndc.gov.tw/News_Content.aspx?n=114AAE178CD95D4C\&sms=DF717169EA26F1A3 $\& s=9628$ F75B06CCA7DD.

Safarov. I. et al, 2017. Utilization of open government data: A systematic literature review of types, conditions, effects and users. Information Polity DOI: 10.3233/IP-160014.

United Nations, 2016. The United Nations E-Government Survey 2016: E-Government in Support of Sustainable Development. New York: United Nations.

United Nations, 2018. The United Nations E-Government Survey 2018: Gearing E-Government to Support Transformation towards sustainable and resilient societies. New York: United Nations.

Viscusi, G. et al, 2014. Assessing Social Value in Open Data Initiatives: A Framework. Future Internet, Vol. 6, No. 3, pp. 498-517.

Weerakkody, V. et al., 2017. Open data and its usability: an empirical view from the Citizen's perspective. Information Systems Frontiers, Vol. 19, No. 2, pp. 285-300.

World Bank, 2014. Open Data for Economic Growth, [online], available: http://www.worldbank.org/content/dam/Worldbank/document/Open-Data-for-Economic-Growth.pdf.

Worthy, B., 2015. The Impact of Open Data in the Uk: Complex, Unpredictable and Political. Public Administration, Vol. 93, No. 3, pp. 788-805. 